\title{
Why has the Ebola outbreak in West Africa been so challenging to control?
}

\author{
Semalulu $T^{1}$, Wong $G^{2^{\star}}$, Kobinger $G^{2}$ and Huston $P^{3}$ \\ ${ }^{1}$ Northern Ontario School of Medicine, Thunder Bay, ON \\ ${ }^{2}$ Public Health Agency of Canada, National Microbiology Laboratory, Winnipeg, MB \\ ${ }^{3}$ Public Health Agency of Canada, Office of the Assistant Deputy Minister, Ottawa, ON \\ *Corresponding author: gary.wong@phac-aspc.gc.ca
}

\section{Abstract}

West Africa is in the midst of the largest Ebola outbreak ever; there have been over 1000 deaths and many new cases are reported each day. The World Health Organization (WHO) declared it an outbreak in March 2014 and on August 6, 2014 the WHO declared the outbreak a public health emergency of international concern. Based on the number of deaths and total number of cases reported to the WHO as of August 11, 2014, the current outbreak has an overall mortality rate of $55 \%$. Outbreak control measures against Ebola virus disease are effective. Why then, has this outbreak been so challenging to control? Ebola is transmitted through bodily fluids and immediately attacks the immune system, then progressively attacks the major organs and the lining of blood vessels. Sierra Leone, Guinea and Liberia are small countries that have limited resources to respond to prolonged outbreaks, especially in rural areas. This has been made more challenging by the fact that health care workers are at risk of contracting Ebola virus disease. Treatment to date has been supportive, not curative and outbreak control strategies have been met with distrust due to fear and misinformation. However, important progress is being made. The international response to Ebola is gaining momentum, communication strategies have been developed to address the fear and mistrust, and promising treatments are under development, including a combination of three monoclonal antibodies that has been administered to two American Ebolainfected health care workers. The National Microbiology Laboratory of the Public Health Agency of Canada (PHAC) has been supporting laboratory diagnostic efforts in West Africa and PHAC has been working with the provinces and territories and key stakeholders to ensure Canada is prepared for a potential Ebola importation.

\section{Introduction}

Four West African countries are in the midst of the largest Ebola outbreak the world has seen. The World Health Organization (WHO) declared it an outbreak in March 2014. On August 6, 2014, the WHO, based on the recommendations of its Emergency Committee, declared the current outbreak a Public Health Emergency of International Concern (PHEIC) (1). As of August 11, 2014, the WHO has reported 1848 cases and 1013 deaths in Guinea, Sierra Leone, Liberia and Nigeria (1). Based on these reported deaths and total number of cases, this outbreak currently has an overall mortality rate of $55 \%$.

The objective of this article is to summarize what we know about Ebola virus disease, current challenges to controlling the outbreak, and progress to date, including Canada's contribution to the outbreak response.

\section{Background}

Ebola belongs to the family Filoviridae, in which most members cause severe hemorrhagic fever in humans. There are five species: Zaire ebolavirus, Sudan ebolavirus, Bundibugyo ebolavirus, Tai forest ebolavirus, and Reston ebolavirus. Each species contains one virus (Table 1) (2, 3). 
Table 1: $\quad$ Species of Genus Ebolavirus $(3,4)$

\begin{tabular}{l|l|l|l}
\hline Species & Virus & Region & Fatality Rate \\
\hline Zaire ebolavirus & EBOV & Africa & $60-90 \%$ \\
\hline Sudan ebolavirus & SUDV & Africa & $40-60 \%$ \\
\hline Bundibugyo ebolavirus & BDBV & Africa & $25 \%$, based on one outbreak \\
\hline Tai forest ebolavirus & TAFV & Africa & Unknown, only one known infection in Ivory Coast \\
\hline Reston ebolavirus & RESTV & Asia & $\begin{array}{l}\text { Not known to cause lethal infections in humans. Lethal in non- } \\
\text { human primates. }\end{array}$ \\
\hline
\end{tabular}

The current outbreak is caused by a new variant of EBOV, the species most virulent in humans (5).

The natural reservoir of EBOV is unknown, but is thought to be fruit bats (6). EBOV is known to cause disease in humans, non-human primates, and other mammals $(4,7)$. EBOV is thought to enter the human population through exposure to the bodily fluids of an infected fruit bat or mammal, especially non-human primates. Human infection with EBOV has been associated with hunting and processing bushmeat (8-10).

Following an incubation period of 2 to 21 days (and is usually 8-10 days), Ebola initially presents with non-specific symptoms (e.g. headaches, fever, and muscle pain). This progresses to a rash, diarrhea and vomiting typically followed by multi-organ failure, hemorrhaging and death. Person-to-person transmission occurs through direct contact with the bodily fluids and tissues of an infected person (2). Those most at risk of infection during outbreaks are family members and caregivers of infected individuals, individuals in contact with dead bodies during funeral preparations and rituals, and health care personnel through safety protocol breaches (e.g. needlestick injury) (11).

Although treatment options to date have been limited, outbreak control measures are effective in arresting transmission when they can be executed properly. These measures include barrier and quarantine methods to limit exposure, early identification, isolation of cases, contact tracing, communication strategies to decrease risky behaviours, and epidemiologic surveillance $(11,12,13)$.

Outbreak control measures for Ebola are effective. Why then, has the West Africa outbreak been so challenging to control?

\section{The Challenges}

\section{The Ebola virus has deadly attack mechanisms}

The Ebola virus enters the host through small skin lesions and mucosal surfaces facilitated by its surface glycoprotein (GP). Upon cell entry, the virus replicates and, as progeny virus buds from the host cell membrane, the infected cell is destroyed $(14,15,16)$. Analysis of tissues from infected human and non-human primates have demonstrated that viral replication occurs initially in leukocytes, epithelial cells, hepatocytes, splenic, adrenal cortical, and endothelial cells (4).

\section{Leukocytes}

Leukocytes - macrophages, monocytes and dendritic cells - are the primary cell targets of infection (17); this has a profound effect on the immune response. Macrophages and monocytes are part of the innate immune response and the body's first line of defense against infections. Cell death of monocytes and macrophages lead to a massive release of cytokines, thus attracting more macrophages to be infected $(18,19,20)$. This causes a positive feedback loop between macrophages and cytokines which can lead to a dysregulated inflammatory response or cytokine storm $(3,19,20,23)$. 
The death of infected dendritic cells means they are incapable of activating the adaptive immune response. Patients with fatal Ebola virus disease show almost no viral antigen specific antibodies due to suppressed B-and T-cell immunity (21). This is caused by anti-inflammatory cytokines released by macrophages, such as interleukin10 (IL-10) (22). Thus, EBOV hyperstimulates the innate immune response and suppresses the adaptive immune response.

\section{Epithelial, hepatic, splenic and adrenal cells}

Infected leukocytes are thought to spread the virus systemically through the lymphatic system and blood. The virus then preferentially attacks epithelial, hepatic, splenic and adrenal cells (4). Infected epithelial cells lining the gut cause gastrointestinal symptoms during the early stages of infection (e.g. vomiting and diarrhea) (4). Infected hepatocytes lead to increased liver enzyme levels and impaired liver function. This may decrease the synthesis of coagulation factors, contributing to coagulation abnormalities (24). Infected splenic cells can lead to necrosis and hemorrhage into the abdominal cavity. Necrosis of adrenal cortical cells affects the regulation of blood pressure, and appears to contribute to septic shock during the later stages of infection (25). The virus eventually reaches all vital organs, leading to progressive organ failure and shock $(4,20)$.

\section{Endothelial cells}

Endothelial cells lining the blood vessels are targeted during later stages of infection. Endothelial impairment is thought to increase vascular permeability that can lead to hemorrhage, a prominent feature of infection in approximately $40-50 \%$ of patients $(5,14)$.

How this pathology links with clinical signs and symptoms are highlighted in Table 2.

Table 2: Pathophysiology and clinical signs and symptoms of Ebola virus infection

\begin{tabular}{|c|c|c|}
\hline & Clinical signs and symptoms & Pathophysiology \\
\hline Early symptoms & $\begin{array}{l}\text { Abrupt onset of fever, chills, malaise, myalgia } \\
\text { Severe sore throat }\end{array}$ & $\begin{array}{l}\text { Infected monocytes and macrophages } \\
\text { release cytokines }\end{array}$ \\
\hline \multirow[t]{8}{*}{ First week } & Systemic: Prostration, lethargy & Cytokines contribute to systemic symptoms \\
\hline & $\begin{array}{l}\text { Gastrointestinal: Anorexia, nausea, } \\
\text { vomiting, abdominal pain, diarrhea (and } \\
\text { progressively bloody diarrhea and } \\
\text { hematemesis) }\end{array}$ & $\begin{array}{l}\text { Viral replication in epithelial and endothelial } \\
\text { cells lead to gastrointestinal symptoms and } \\
\text { bleeding }\end{array}$ \\
\hline & $\begin{array}{l}\text { Cardiac: Chest pain dyspnea, shortness of } \\
\text { breath, cough, nasal discharge }\end{array}$ & $\begin{array}{l}\text { Viral replication and necrosis in cardiac } \\
\text { tissues }\end{array}$ \\
\hline & $\begin{array}{l}\text { Splenic: Fever, abdominal pain, hemorrhage, } \\
\text { if rupture into peritoneal cavity }\end{array}$ & Viral replication and necrosis \\
\hline & $\begin{array}{l}\text { Hepatic: Elevated liver enzymes and } \\
\text { coagulation abnormalities }\end{array}$ & $\begin{array}{l}\text { Liver cells are infected leading to cell death } \\
\text { and affecting clotting factor production }\end{array}$ \\
\hline & $\begin{array}{l}\text { Vascular: Conjunctival injection, postural } \\
\text { hypotension, edema }\end{array}$ & $\begin{array}{l}\text { Endothelial cells are taken over and } \\
\text { cytokines released, leading to increased } \\
\text { vascular permeability }\end{array}$ \\
\hline & $\begin{array}{l}\text { Neurologic: Headache, confusion, } \\
\text { encephalitis, seizure, coma }\end{array}$ & $\begin{array}{l}\text { Viral replication in brain tissue and vascular } \\
\text { dysfunction }\end{array}$ \\
\hline & $\begin{array}{l}\text { Skin: Maculopapular rash with varying } \\
\text { degrees of erythema and desquamation }\end{array}$ & Endothelial leakage \\
\hline
\end{tabular}




\begin{tabular}{|c|c|c|}
\hline & Clinical signs and symptoms & Pathophysiology \\
\hline \multirow[t]{2}{*}{ Complications } & $\begin{array}{l}\text { Hemorrhage } \\
\text { Petechiae, ecchymoses, uncontrolled } \\
\text { bleeding from venipuncture sites, epistaxis, } \\
\text { visceral hemorrhagic effusions and other } \\
\text { mucosal hemorrhages }\end{array}$ & $\begin{array}{l}\text { Infected hepatic cells result in elevated liver } \\
\text { enzymes and coagulation abnormalities } \\
\text { Damaged endothelial cells lead to increased } \\
\text { vascular permeability }\end{array}$ \\
\hline & $\begin{array}{l}\text { Shock and hypotension } \\
\text { Severe metabolic disturbances } \\
\text { Disseminated intravascular coagulation and } \\
\text { hypovolemic shock }\end{array}$ & $\begin{array}{l}\text { Direct viral damage of tissues and organs } \\
\text { may lead to organ failure and shock. } \\
\text { Infected adrenal cells fail to regulate blood } \\
\text { pressure, contributing to hypotension and } \\
\text { septic shock. } \\
\text { Diffuse coagulopathy }\end{array}$ \\
\hline $\begin{array}{l}\text { Laboratory } \\
\text { findings }\end{array}$ & $\begin{array}{l}\text { Early leucopenia, lymphopenia and } \\
\text { subsequent neutrophilia, thrombocytopenia, } \\
\text { prolonged prothrombin and partial } \\
\text { thromboplastin times } \\
\text { High serum aminotransferase levels } \\
\text { Hyperproteinemia and proteinuria }\end{array}$ & $\begin{array}{l}\text { Infected dendritic cells impair immune } \\
\text { response } \\
\text { Uncontrolled upregulation of cytokines and } \\
\text { chemokines (cytokine storm) } \\
\text { Widespread viral replication and cell death in } \\
\text { spleen, kidney, liver, gonads, etc. }\end{array}$ \\
\hline
\end{tabular}

\section{Elimination of the reservoir is not feasible}

The prevalence and extent of the EBOV reservoir amongst wild animals is unknown, so sporadic cases of transmission from animals to humans cannot be prevented.

\section{Treatment is supportive, not curative}

There are currently no approved therapeutic treatments for Ebola. Until recently, treatment focused on rehydration, electrolyte management, antibiotics and antivirals to treat secondary infections and medications to control pain, fever and gastrointestinal distress (2).

\section{The outbreak has reached urban areas}

Historically, Ebola virus disease has been responsible for smaller outbreaks in the remote forests of Sub-Saharan Africa that have typically involved animal-to-human transmission and sporadic human-to-human transmission. This outbreak marks the first time EBOV has appeared in a capital city and has been imported by an infected person into Africa's most populous country, Nigeria. The unprecedented size and location of the outbreak, combined with the fact that the virus is now circulating in densely populated urban centers, sets up the conditions for sustained human-to-human transmission, making the outbreak even more challenging to control (1).

\section{Affected countries have challenges in health care infrastructure}

Sierra Leone, Guinea and Liberia are small countries that have limited resources to respond to prolonged outbreaks, especially in rural areas. This is the first time that West Africa has had to deal with an EBOV outbreak, therefore most primary health workers did not have any prior experience dealing with this virus. Limited surveillance and reporting systems may have delayed outbreak identification and the subsequent global response. The WHO has identified these issues as gaps in the outbreak response $(1,26)$.

\section{Health care workers are at risk of infection}

The WHO has reported health-facility transmission as a central issue during the current outbreak (1). Health care workers are at risk of contracting EBOV while caring for infected patients through accidental exposure to infected bodily fluids. To date, more than 170 health care workers have been infected and at least 81 have died (27). 
These deaths have discouraged some health care workers and international organizations from participating in treatment and control efforts (1).

\section{Outbreak control strategies have been met with distrust}

Persistent community resistance has been identified as a major challenge in the health sector response to the outbreak (1). Effective prevention and control strategies have been undermined by fear, mistrust and misinformation within affected communities, leading some to believe that medical staff have brought the virus to the country. This has resulted in people refusing to cooperate with medical personnel, helping patients escape isolation wards, and exhibiting hostile behaviour $(1,26,28)$. Traditional burial practices also pose a major risk to close relatives, since they typically involve the cleaning and rubbing of dead bodies that may have a high load of Ebola virus. The recommendation that these burial practices be performed by outbreak response team members has been perceived to conflict with beliefs and cultural practices (26).

\section{Progress to date}

\section{The international response is building momentum}

International aid and resources have been increasingly directed to West Africa to control the EBOV outbreak. The WHO has coordinated efforts to scale up the human and financial resources necessary to effectively conduct infection prevention and control activities and to implement infrastructure needed to manage future outbreaks, such as strengthening the surveillance and laboratory capacities. Numerous non-governmental organizations, including Médecins Sans Frontières, Save the Children, and religious organizations have been working on the ground to help stop the spread of this disease (1).

Based on the deliberations of an Emergency Committee, the WHO Director General has made a number of recommendations, including: affected states should declare the outbreak a national emergency and establish an emergency operation centre to coordinate support and response efforts; exit screening be conducted at all international airports, seaports and major land crossings to identify individuals with unexplained febrile illness; appropriate contact management; and all states should enhance their capacity to detect, investigate and manage Ebola cases through improved surveillance, laboratory diagnostic support and rapid response (29).

Canada has joined other nations, organizations, and the WHO by providing financial and technical support. As of August 8, 2014, Canada has contributed over $\$ 5$ million towards humanitarian, infection control and security interventions in West Africa (30). As a member of the WHO Global Outbreak Alert and Response Network (GOARN), Canada provides technical and human resources towards the identification and response to significant international outbreaks (31).

The National Microbiology Laboratory (NML) of the Public Health Agency of Canada (PHAC) has worked closely with the WHO to provide rapid diagnostic support in a mobile laboratory in Sierra Leone (32).

Within Canada, PHAC is taking the lead on national preparedness for Ebola cases, working closely with the provinces and territories and all affected stakeholders. Case definitions, infection control guidelines, public health management of cases and contacts associated with Ebola virus disease, environmental decontamination, biosafety guidelines and more are currently being updated. The Agency is also facilitating the development of specific clinical care guidelines with the Association of Medical Microbiology and Infectious Disease Canada, the Canadian Critical Care Society, and the Canadian Association of Emergency Physicians. 


\section{Communication strategies are being implemented to address fears and misconceptions}

An assessment of the current outbreak led by Dr. Luis Sambo, the WHO Regional Director for Africa, has recommended that affected governments scale up national resources to promote behavioural change while respecting cultural practices (1). Local collaborations (e.g. training community members to identify contacts, and working with local leaders to effectively disseminate the correct information on EBOV) are being used to dispel misconceptions and strengthen control strategies (26). Collaborations with religious, community and tribal leaders are being used to disseminate information $(26,28)$. These messages are also being spread by television and radio (33).

\section{Investigational therapies are under development}

Several experimental treatments are currently under development $(2,34)$. Two infected Americans received an experimental drug, which contains three monoclonal human-mouse chimeric antibodies manufactured in the plant Nicotiana benthamiana (35). These antibodies demonstrated $100 \%$ protection against EBOV in infected cynomolgus macaques(36).

Another investigational treatment uses small interfering RNAs specific to certain EBOV genes to inhibit virus replication. A study demonstrated $66 \%$ and $100 \%$ protection from EBOV in macaques after four and seven postexposure treatments, respectively (37).

Several experimental vaccines have also shown promise against EBOV in nonhuman primates, including an adenovirus-based and a vesicular stomatitis virus (VSV)-based vaccine. For example, the VSV-based vaccine has demonstrated high protective efficacy against EBOV disease, with an absence of noticeable adverse events in non-human primates (38-40). Discussions are ongoing about fast tracking both the adenovirus and the VSV based Ebola vaccines for Phase 1 clinical trials.

The use of experimental treatments on two Americans infected with EBOV has led to a WHO-hosted discussion on the ethical considerations of including such treatments in the response efforts $(1,41)$.

\section{Conclusion}

There are a number of factors that make the Ebola virus outbreak in West Africa a challenge to control. The EBOV has efficient ways to paralyze host defence mechanisms and attack vital organs. It resides in a poorly understood wildlife reservoir and has emerged in countries that have challenges in both health care capacity and risk communication. All these factors have occurred in the context of increasing global travel.

Canada has been an integral part of the global response through sending money, providing laboratory support, developing a vaccine and post exposure treatment, and collaborating internationally. The Public Health Agency of Canada will continue to work with its partners and coordinate the national response to enable the optimal detection, investigation, management and reporting of any potential cases of EBOV within Canada.

The WHO has identified the Ebola outbreak as a public health emergency of international concern. This will continue to require national and international collaboration and the ongoing vigilance of front line health care and public health professionals to end the outbreak in West Africa and prevent its global spread.

\section{Acknowledgements}

Dr. Huston is the Scientific Editor of the Canada Communicable Disease Report and recused herself from the editorial decisions involved in this manuscript. Many thanks to Dr. Tom Wong for taking on the Editor role for this Rapid Communication. Thank you to Mike Drebot and Tim Booth for their support in developing this manuscript and the reviewers who offered timely and useful feedback while participating in response efforts. 


\section{References}

(1) World Health Organization. Global alert and response: Ebola virus disease (EVD). World Health Organization cited 2014]. http://www.who.int/csr/don/archive/disease/ebola/en/

(2) World Health Organization. Ebola virus disease: background and summary. World Health Organization cited July 2014]. http://www.who.int/csr/don/2014 04 ebola/en/

(3) Wong G, Kobinger GP, Qiu X. Characterization of host immune responses in Ebola virus infections. Expert Rev Clin Immunol 2014 Jun;10(6):781-90.

(4) Feldmann H, Geisbert TW. Ebola haemorrhagic fever. Lancet. 2011 Mar 5;377(9768):849-62.

(5) Baize S, Pannetier D, Oestereich L, Rieger T, Koivogui L, Magassouba N, Soropogui B, Sow MS, Keita S, De Clerck H, Tiffany A, Dominguez G, Loua M, Traore A, Kolie M, Malano ER, Heleze E, Bocquin A, Mely S, Raoul H, Caro V, Cadar D, Gabriel M, Pahlmann M, Tappe D, Schmidt-Chanasit J, Impouma B, Diallo AK, Formenty P, Van Herp M, Gunther S. Emergence of Zaire Ebola virus disease in Guinea - preliminary report. N Engl J Med2014 Apr 16.

(6) Leroy EM, Kumulungui B, Pourrut X, Rouquet P, Hassanin A, Yaba P, Delicat A, Paweska JT, Gonzalez JP, Swanepoel R. Fruit bats as reservoirs of Ebola virus. Nature . 2005 Dec 1;438(7068):575-6.

(7) Weingartl HM, Nfon C, Kobinger G. Review of Ebola virus infections in domestic animals. Dev Biol (Basel) . 2013;135:211-8.

(8) Leroy EM, Rouquet P, Formenty P, Souquiere S, Kilbourne A, Froment JM, Bermejo M, Smit S, Karesh W, Swanepoel R, Zaki SR, Rollin PE. Multiple Ebola virus transmission events and rapid decline of central African wildlife. Science. 2004 Jan 16;303(5656):387-90.

(9) Nkoghe D, Kone ML, Yada A, Leroy E. A limited outbreak of Ebola haemorrhagic fever in Etoumbi, Republic of Congo, 2005. Trans R Soc Trop Med Hyg . 2011 Aug;105(8):466-72.

(10) Georges-Courbot MC, Sanchez A, Lu CY, Baize S, Leroy E, Lansout-Soukate J, Tevi-Benissan C, Georges AJ, Trappier SG, Zaki SR, Swanepoel R, Leman PA, Rollin PE, Peters CJ, Nichol ST, Ksiazek TG. Isolation and phylogenetic characterization of Ebola viruses causing different outbreaks in Gabon. Emerg Infect Dis. 1997 Jan-Mar;3(1):59-62.

(11) MacNeil A, Rollin PE. Ebola and Marburg hemorrhagic fevers: Neglected tropical diseases? PLoS Negl Trop Dis . 2012 Jun;6(6):e1546.

(12) Raabe VN, Borcherta M. Infection control during filoviral hemorrhagic fever outbreaks. J Glob Infect Dis. 2012;4(1):69-74.

(13) World Health Organization. Case definition recommendations for Ebola or Marburg Virus Diseases. Geneva, Switzerland: World Health Organization April 2014 cited August 2014]; [3].

http://www.who.int/csr/resources/publications/ebola/ebola-case-definition-contact-en.pdf?ua=1

(14) Hoenen T, Groseth A, Falzarano D, Feldmann H. Ebola virus: Unravelling pathogenesis to combat a deadly disease. Trends Mol Med . 2006 May;12(5):206-15.

(15) Sullivan N, Yang ZY, Nabel GJ. Ebola virus pathogenesis: Implications for vaccines and therapies. J Virol. 2003 Sep;77(18):9733-7. 
(16) Beniac DR, Melito PL, Devarennes SL, Hiebert SL, Rabb MJ, Lamboo LL, Jones SM, Booth TF. The organisation of Ebola virus reveals a capacity for extensive, modular polyploidy. PLoS One . 2012;7(1):e29608.

(17) Geisbert TW, Young HA, Jahrling PB, Davis KJ, Larsen T, Kagan E, Hensley LE. Pathogenesis of Ebola hemorrhagic fever in primate models: Evidence that hemorrhage is not a direct effect of virusinduced cytolysis of endothelial cells. Am J Pathol . 2003 Dec;163(6):2371-82.

(18) Bray M, Geisbert TW. Ebola virus: The role of macrophages and dendritic cells in the pathogenesis of Ebola hemorrhagic fever. Int J Biochem Cell Biol. 2005 Aug;37(8):1560-6.

(19) Feldmann H, Bugany H, Mahner F, Klenk HD, Drenckhahn D, Schnittler HJ. Filovirus-induced endothelial leakage triggered by infected monocytes/macrophages. J Virol . 1996 Apr;70(4):220814.

(20) Zampieri CA, Sullivan NJ, Nabel GJ. Immunopathology of highly virulent pathogens: Insights from Ebola virus. Nat Immunol . 2007 Nov;8(11):1159-64.

(21) Wong G, Richardson JS, Pillet S, Patel A, Qiu X, Alimonti J, Hogan J, Zhang Y, Takada A, Feldmann H, Kobinger GP. Immune parameters correlate with protection against Ebola virus infection in rodents and nonhuman primates. Sci Transl Med . 2012 Oct 31;4(158):158ra146.

(22) Said EA, Dupuy FP, Trautmann L, Zhang Y, Shi Y, El-Far M, Hill BJ, Noto A, Ancuta P, Peretz Y, Fonseca SG, Van Grevenynghe J, Boulassel MR, Bruneau J, Shoukry NH, Routy JP, Douek DC, Haddad EK, Sekaly RP. Programmed death-1-induced interleukin-10 production by monocytes impairs CD4+ T cell activation during HIV infection. Nat Med. 2010 Apr;16(4):452-9.

(23) Wauquier N, Becquart P, Padilla C, Baize S, Leroy EM. Human fatal Zaire Ebola virus infection is associated with an aberrant innate immunity and with massive lymphocyte apoptosis. PLoS Negl Trop Dis . 2010 Oct 5;4(10):10.1371/journal.pntd.0000837.

(24) Geisbert TW, Jahrling PB, Hanes MA, Zack PM. Association of Ebola-related Reston virus particles and antigen with tissue lesions of monkeys imported to the United States. J Comp Pathol . 1992 Feb;106(2):137-52.

(25) Ryabchikova El, Kolesnikova LV, Luchko SV. An analysis of features of pathogenesis in two animal models of Ebola virus infection. J Infect Dis . 1999 Feb;179 Suppl 1:S199-202.

(26) Andrew Green. Ebola emergency meeting establishes new control centre. Lancet. 2014;384:118.

(27) World Health Organization. Barriers to rapid containment of the Ebola outbreak. Geneva, Switzerland: World Health Organization cited August 2014]. http://www.who.int/csr/disease/ebola/overview-august-2014/en/

(28) World Health Organization. Busting the myths about Ebola is crucial to stop the transmission of the disease in Guinea. Geneva, Switzerland: World Health Organization cited July 2014]. http://www.who.int/features/2014/ebola-myths/en/

(29) World Health Organization. WHO Statement on the Meeting of the International Health Regulations Emergency Committee Regarding the 2014 Ebola Outbreak in West Africa Geneva, Switzerland: World Health Organization August 8, 2014 cited August 2014]. http://who.int/mediacentre/news/statements/2014/ebola-20140808/en/ 
(30) Government of Canada. Canada's response to the Ebola outbreak in the West Africa region Government of Canada August 8, 2014 cited August 2014].

http://www.international.gc.ca/media/dev/news-communiques/2014/08/08b bg.aspx?lang=eng

(31) World Health Organization. Global alert and response: Global Outbreak Alert and Response Network Geneva, Switzerland: World Health Organization cited August 2014]. http://www.who.int/csr/outbreaknetwork/en/

(32) Public Health Agency of Canada. Statement from Dr. Gregory Taylor, the Deputy Chief Public Health Officer, on the Ebola Outbreak in Africa . Public Health Agency of Canada July 2014 cited July 2014]. http://www.phac-aspc.gc.ca/cpho-acsp/statements/20140730-eng.php

(33) World Health Organization. Involving everyone: social mobilization is key in an Ebola outbreak response [Internet]. World Health Organization May 2014 cited July 2014]. http://www.who.int/features/2014/social-mobilisation/en/

(34) Leroy EM, Gonzalez JP, Baize S. Ebola and Marburg haemorrhagic fever viruses: Major scientific advances, but a relatively minor public health threat for Africa. Clin Microbiol Infect 2011 Jul;17(7):964-76.

(35) Mapp Biopharmaceutical. ZMapp Information Sheet San Diego, California: Mapp Biopharmaceutical 2014 cited August 2014]. Available from: http://mappbio.com/zmapinfo.pdf

(36) Qiu X, Audet J, Wong G, Fernando L, Bello A, Pillet S, Alimonti JB, Kobinger GP. Sustained protection against Ebola virus infection following treatment of infected nonhuman primates with ZMAb. Sci Rep 2013 Nov 28;3:3365.

(37) Geisbert TW, Lee AC, Robbins M, Geisbert JB, Honko AN, Sood V, Johnson JC, de Jong S, Tavakoli I, Judge A, Hensley LE, Maclachlan I. Postexposure protection of non-human primates against a lethal Ebola virus challenge with RNA interference: A proof-of-concept study. Lancet2010 May 29;375(9729):1896-905.

(38) Jones SM, Feldmann H, Ströher U, Geisbert JB, Fernando L, Grolla A, Klenk HD, Sullivan NJ, Volchkov VE, Fritz EA, Daddario KM, Hensley LE, Jahrling PB, Geisbert TW. Live attenuated recombinant vaccine protects nonhuman primates against Ebola and Marburg viruses. Nat Med. 2005 Jul;11(7):786-90. Epub 2005 Jun 5.

(39) Gunther S, Feldmann H, Geisbert TW, Hensley LE, Rollin PE, Nichol ST, et al. Management of accidental exposure to Ebola virus in the biosafety level 4 laboratory, Hamburg, Germany. J Infect Dis. 2011;204 Suppl 3:S785-90

(40) Geisbert TW, Daddario-Dicaprio KM, Lewis MG, Geisbert JB, Grolla A, Leung A, Paragas J, Matthias L, Smith MA, Jones SM, Hensley LE, Feldmann H, Jahrling PB. Vesicular stomatitis virus-based Ebola vaccine is well-tolerated and protects immunocompromised nonhuman primates. PLoS Pathog. 2008 Nov;4(11): Epub 2008 Nov 28.

(41) WHO statement. Ethical considerations for use of unregistered interventions for Ebola virus disease. August 12, 2014. http://www.who.int/mediacentre/news/statements/2014/ebola-ethicalreview-summary/en/ 